\title{
Nano-selenium Supplementation Increases Selenoprotein (Sel) Gene Expression Profiles and Milk Selenium Concentration in Lactating Dairy Cows
}

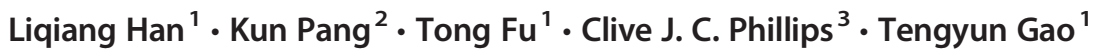

Received: 26 September 2019 / Accepted: 30 March 2020 / Published online: 23 April 2020

(C) The Author(s) 2020

\begin{abstract}
Supplementation with selenium is common for dairy cows, but the importance of selenium source is not clear. This study aimed to compare nano-selenium (Nano-Se) and sodium selenite supplements for dairy cows on lactation performance, milk Se levels and selenoprotein (Sel) gene expression. Twelve multiparous Holstein cows were randomly divided into two groups: a control group fed a basal diet plus $0.30 \mathrm{mg} \mathrm{Se} / \mathrm{kg}$ of DM as sodium selenite or Nano-Se for 30 days. Dry matter intake, milk yield and composition were not affected by dietary Se source $(P>0.05)$; however, the milk total Se levels and milk glutathione peroxidase (GSH-Px) activities were higher with Nano-Se supplementation than sodium selenite $(P<0.05)$. At the end of the experiment, Nano-Se supplementation significantly increased plasma Se levels and GSH-Px activity, compared with the sodium selenite supplement. The mRNA expression levels of glutathione peroxidase 1, 2 and 4; thioredoxin reductase 2 and 3; and selenoproteins W, T, K and F were markedly upregulated $(P<0.05)$ in the mammary gland of the Nano-Se group. Thus, the source of selenium plays an important role in the antioxidant status and in particular the Sel gene expression in the mammary glands of dairy cows, both being stimulated by nano sources.
\end{abstract}

Keywords Milk $\cdot$ Nano-Se $\cdot$ Glutathione peroxidase $\cdot$ Selenoprotein $\cdot$ Dairy cow

\section{Introduction}

Selenium (Se) is a trace element nutrient that acts as a cofactor of antioxidant enzymes (such as glutathione peroxidases) and

Liqiang Han and Kun Pang contributed equally to this work.

Tengyun Gao

muyijggx@henau.edu.cn

Liqiang Han

qlhan2001@henau.edu.cn

Kun Pang

qinqingming@xyafu.edu.cn

Tong Fu

muyijx@henau.edu.cn

1 College of Animal Science and Veterinary Medicine, Henan Agricultural University, Zhengzhou 450002, China

2 College of Animal Science and Veterinary Medicine, Xinyang Agriculture and Forestry University, Xinyang 464000, China

3 Centre for Animal Welfare and Ethics, School of Veterinary Science, The University of Queensland, Gatton Campus, Gatton 4343, Australia affects the antioxidant activities and immune functions of animals [1]. Se deficiency may cause immune system or nerve damage and several diseases in animals [2, 3]. Se supplementation has antioxidant effects, thereby increasing cellular defence against oxidative stress $[4,5]$. Free radicals damage cells and limit the bactericidal effects of a neutrophil release. Therefore, Se is essential for the health of animals, including humans for whom an allowance of $\geq 55 \mu \mathrm{g} /$ day decreases the risk of cancer [6].

Milk potentially makes an important contribution to a person's daily intake of Se, as consumption of $100 \mathrm{~g}$ milk/day will provide at least $10 \%$ of the daily Se requirement for adults [7]. Therefore, supplements of dietary Se to increase milk Se content have been developed in cows [8]. Early studies found that after feeding inorganic forms of Se, such as sodium selenite, small amounts of Se were transferred to milk [9]. Dietary organic Se (Se yeast) have also resulted in increased Se concentrations in blood and milk, associated with a reduction in oxidative stress status in cows [10-13].

Nano-selenium (Nano-Se) is a new method of supplementing with Se that uses a protein as a dispersant and the red element $\mathrm{Se}$ as a membrane. Nano-Se contains more active centres than conventional Se products, with 
higher biological activity and lower toxicity, and is more effective at increasing selenoprotein (Sel) expression [14-16]. Elemental Se is biologically inert, but supplements with nanometre dimensions, typically 20-60 nm, may have improved absorption characteristics. For example, it has been reported that Nano-Se supplementation had higher Se deposition efficiency than sodium selenite in laying hens [15]. Information on the effects of Nano-Se supplementation on bovine lactation performance and milk Se is limited. Therefore, the aim of this work was to evaluate the effects of Nano-Se supplementation on lactation performance, milk Se concentration and mammary Sel expression in mid-lactation dairy cows in comparison with conventional sodium selenite.

\section{Materials and Methods}

\section{Ethics Statement}

All experimental procedures were approved by the Animal Care and Use Committee of Henan Agricultural University, which was performed according to the Guidelines for Experimental Animal of the Ministry of Science and Technology (2006, Beijing, China).

\section{Diets and Feeding}

Twelve multiparous Holstein cows $(2.5 \pm 0.3$ parity, $141 \pm$ 27 days in milk [DIM], $583 \pm 34.6 \mathrm{~kg} \mathrm{BW}, 28.6 \pm 2.4 \mathrm{~kg}$ milk/day) were randomly divided into two groups with six cows in each group. Treatment diets consisted of a basal diet plus $0.30 \mathrm{mg} \mathrm{Se} / \mathrm{kg} \mathrm{DM}$ from sodium selenite (analytical grade, $1 \%$ Se content, Xingjia Bio-Engineering Co., Ltd., Changsha, China) for the control group and a basal diet plus $0.30 \mathrm{mg} \mathrm{Se} / \mathrm{kg}$ DM from Nano-Se $(0.01 \%$ Se content, Bosar Biotechnology Research Co. Ltd., China) for the Nano-Se group. The experimental cows were fed a total mixed ration (TMR). The experimental period was 35 days, with 5 days of adaptation and 30 days of sampling. Cows were housed in a naturally ventilated barn, fed individually in their own troughs. They were milked three times daily at 6:00, 14:00 and 20:00 $\mathrm{h}$ and were fed ad libitum a total mixed ration (TMR) after each milking. The ingredients and chemical composition of the diets are reported in Table 1. Rations were formulated to meet the cow's predicted requirements for minerals and vitamins according to the National Research Council (NRC, 2001).

\section{Milk Sampling and Feed Dry Matter Intake Recording}

Feed offered and refused were measured daily for each cow and recorded throughout the experimental period to calculate DM intake. Milk production was recorded daily, and
Table 1 Ingredients and chemical composition of the basal diets of cows

\begin{tabular}{|c|c|}
\hline Composition & Content \\
\hline \multicolumn{2}{|l|}{ Ingredient, in $\mathrm{g} / \mathrm{kg} \mathrm{DM}$} \\
\hline Corn silage & 420 \\
\hline Ground corn & 38 \\
\hline Steam-flaked corn & 155 \\
\hline Soybean meal & 85 \\
\hline Cottonseed & 40 \\
\hline Oat hay & 43 \\
\hline Alfalfa hay & 132 \\
\hline Soybean hull & 54 \\
\hline Yeast $\mathrm{XP}^{1}$ & 4.2 \\
\hline $\mathrm{NaCl}$ & 3.8 \\
\hline Limestone & 5.8 \\
\hline $\mathrm{NaHCO}_{3}$ & 6.2 \\
\hline $\mathrm{KHCO}_{3}$ & 5.4 \\
\hline $\mathrm{MgO}$ & 2.6 \\
\hline Premix $^{2}$ & 5 \\
\hline \multicolumn{2}{|c|}{ Chemical composition, in $\mathrm{g} / \mathrm{kg} \mathrm{DM}$} \\
\hline Crude protein & 167 \\
\hline Neutral detergent fibre & 315 \\
\hline Acid detergent fibre & 208 \\
\hline Ether extract & 56 \\
\hline Net energy of diet, $\mathrm{Mcal} / \mathrm{kg}^{3}$ & 1.81 \\
\hline $\mathrm{Ca}$ & 8.1 \\
\hline $\mathrm{P}$ & 4.5 \\
\hline $\mathrm{Se}(\mathrm{mg} / \mathrm{kg} \mathrm{DM})$ & 0.05 \\
\hline \multicolumn{2}{|c|}{${ }^{1}$ Purchased from Diamond V Co., USA } \\
\hline \multicolumn{2}{|c|}{$\begin{array}{l}{ }^{2} \text { Composition in } \mathrm{kg}^{-1} \mathrm{DM} \text { : } 670,000 \mathrm{IU} \text { of } \\
\text { vitamin A; } 92,000 \mathrm{IU} \text { of vitamin D; } \\
3750 \mathrm{IU} \text { of vitamin E; } 700 \mathrm{mg} \text { of niacin; } \\
2000 \mathrm{mg} \text { of } \mathrm{Cu} ; 4000 \mathrm{mg} \text { of } \mathrm{Zn} ; 330 \mathrm{mg} \text { of } \\
\mathrm{Mn} ; 65 \mathrm{mg} \text { of } \mathrm{I} ; 37 \mathrm{mg} \text { of } \mathrm{Co} \text {. }\end{array}$} \\
\hline${ }^{3}$ Calculated using NRC & \\
\hline
\end{tabular}

consecutive morning, midday and evening samples were collected every 7 days (day 1 , day 7 , day 14 , day 21 , day 28 ). Milk samples were divided into two, one stored with preservative at $4{ }^{\circ} \mathrm{C}$ for the analysis of fat, protein and lactose by infrared spectrophotometry (Foss 120 Milko-Scan, Foss Electric, Denmark), and the second stored at $-80{ }^{\circ} \mathrm{C}$ for later chemical analysis. Samples of TMR were collected once per week and stored at $-20{ }^{\circ} \mathrm{C}$ for later chemical analysis.

\section{Blood Samples}

Blood samples were collected from the coccygeal vein before feeding using evacuated tubes containing heparin on the 30th day of the experiment. After blood collection, plasma was obtained by centrifugation at $2000 \times g$ for $30 \mathrm{~min}$ at $4{ }^{\circ} \mathrm{C}$. 
Aliquots of plasma were frozen $\left(-80{ }^{\circ} \mathrm{C}\right)$ until further analysis.

\section{Chemical Analyses}

The concentrations of Se in feed sample, milk and plasma samples were analysed by the fluorometric method [11]. Briefly, the samples were digested with perchloric acid and nitric acid. After adding hydroxylamine and EDTA solutions to the digestive solution, the $\mathrm{pH}$ value of the mixed solution was adjusted to 1.5 . Then, a 2,3-diaminonaphtalene solution was added. The resulting solution was incubated in a boiling water bath for $5 \mathrm{~min}$ in darkness and extracted with cyclohexane after cooling. The fluorescence intensity of the organic phase was determined by a fluorescence spectrophotometer (Hitachi F-7000, Japan), and the Se concentrations of the samples were quantified with external calibration using a regression equation.

Milk samples were centrifuged at $10,000 \times g$ for $30 \mathrm{~min}$ at $4{ }^{\circ} \mathrm{C}$, after which the upper layer of milk fat was removed and the resultant milk whey was diluted 1:10 with PBS to detect the GSH-Px enzyme activity. The GSH-Px activity of both the milk whey and plasma was measured using a glutathione peroxidase (GSH-Px) assay kit (A005, colorimetric method, from Nanjing Jiancheng Bioengineering Institute) according to the manufacturer's instructions.

\section{Sel Gene Expression in the Mammary Gland}

A biopsy sample of mammary gland tissue $(n=5)$ was obtained percutaneously on day 30 , as described previously [17]. Total RNA was isolated from 50 to $60 \mathrm{mg}$ of mammary gland tissue using an miRNeasy kit (Qiagen) following the manufacturer's protocols. Samples were treated with DNaseI (Qiagen) and quantified using a NanoDrop ND-1000 (NanoDrop Technologies). First-strand cDNA was synthesized using Oligo(dT)20 and Superscript II reverse transcriptase. A comprehensive literature search [18-22] was conducted to select the Sel genes to be evaluated, including glutathione peroxidase $1 \sim 4$ (GPX1 4), thioredoxin enzyme1 3 (TXNRD1 3) and Selenoprotein gene (M, W, F, P, etc.). Primers were designed according to the NCBI database using the Bos taurus sequence (https://www.ncbi.nlm.nih.gov/) to produce PCR products. Gene symbols and primer sequences are presented in Table 2. Real-time PCR was then performed as previously described [17]. The relative mRNA expression of the target gene was normalized with the geometric mean of UXT, RPS9 and RPS15 [23].

\section{Statistical Analysis}

Data statistics and differences among groups were analysed by SPSS 25.0 (SPSS/IBM Corp., Chicago, IL). The data describing DM intake, milk yield, milk composition and milk Se were analysed for significant differences using a repeated measures general linear model. The model included the factors of diet $(D)$, time $(T)$ and their interactions $(\mathrm{D} \times \mathrm{T})$. Differences between means were tested using the LSD test. GPX-PX activity, blood parameters and gene expression were analysed using Student's $t$ tests. A $P$ value $<0.05$ was considered statistically significant.

\section{Results}

\section{Lactation Performance}

There were no differences between treatments, dates or interactions between the two $(P>0.05)$ for cow DMI, milk yield, milk protein, fat or lactose concentration (Table 3 ). However, Nano-Se supplementation led to greater milk Se than the control treatment $(+7.38 \mu \mathrm{g} / \mathrm{L} \mathrm{kg} / \mathrm{d}, P<0.01$; Table 3$)$.

\section{GSH-Px Activity in Milk}

The milk GSH-Px activity is presented in Fig. 1. Milk in the Nano-Se group had higher GSH-Px activity than the control treatment at days 7, 14, 21 and $28(P<0.05$ or $P<0.01)$.

\section{Antioxidant Capacity in Blood}

Compared with controls, cows in the Nano-Se treatment had increased plasma Se and plasma activity of GSH-Px $(P<0.01$, Table 4).

\section{Sel Gene Expression in the Mammary Gland}

Compared with controls, Nano-Se supplementation significantly increased mRNA expression of GPX1, GPX2, GPX4, TXNRD2, TXNRD3, SelW, SelT, SelK and SelF in the mammary gland. Expression of mRNA of other Sel genes (GPX3, TXNRD 1, SelM, SelH, SelI, SelO, SelS and SelV) was not affected by the Nano-Se treatment $(P>0.05$, Table 5).

\section{Discussion}

In the present research, the Se concentration in the basal diet was measured as $0.05 \mathrm{mg} / \mathrm{kg} \mathrm{DM}$, which is the critical level for Se deficiency in cattle. A meta-analysis has indicated that cows supplemented with Se yeast $(6 \mathrm{mg} / \mathrm{head})$ each day had increased milk Se levels [9]. As an indicator of Se status in cows, concentrations of serum Se between 80 and $160 \mu \mathrm{g} / \mathrm{L}$ have been reported as adequate [24]. In the present study, we used a dose of $0.30 \mathrm{mg} \mathrm{Se} / \mathrm{kg} \mathrm{DM}$, which meant that cows fed the sodium selenite and Nano-Se received $6.4 \mathrm{mg}$ and $6.2 \mathrm{mg}$ 
Table 2 Primer sequences of Sel genes for real-time PCR

\begin{tabular}{|c|c|c|c|}
\hline Gene symbol (GenBank number) & Primer sequence $\left(5^{\prime}-3^{\prime}\right)$ & Length of products & Gene name \\
\hline GPX1 (NM_174076) & $\begin{array}{l}\text { F: AACGTAGCATCGCTCTGAGG } \\
\text { R: GATGCCCAAACTGGTTGCAG }\end{array}$ & 121 & Glutathione peroxidase 1 \\
\hline GPX2 (NM_001163139) & $\begin{array}{l}\text { F: TGAGCATTCACTGTGCCCTC } \\
\text { R: GGAAGGAAACAGGCAGACCA }\end{array}$ & 104 & Glutathione peroxidase 2 \\
\hline GPX3 (NM_174077) & $\begin{array}{l}\text { F: TTGGTCTGGTCATTCTGGGC } \\
\text { R: CCCCACCTGGTCGAACATAC }\end{array}$ & 105 & Glutathione peroxidase 3 \\
\hline GPX4 (NM_174770) & $\begin{array}{l}\text { F: CCGAGATGAGCTTTAGCCGT } \\
\text { R: TGGCTGAAAATTCGTGCATGG }\end{array}$ & 144 & Glutathione peroxidase 4 \\
\hline TXNRD1 (NM_174625) & $\begin{array}{l}\text { F: CATTGCCACTGGTGAAAGGC } \\
\text { R: CCAACCACCAGGGTCTTACC }\end{array}$ & 117 & Thioredoxin reductase 1 \\
\hline TXNRD2 (NM_174626) & $\begin{array}{l}\text { F: ACCACGTGAAGTCCCTGAAC } \\
\text { R: CCTTTGGAGACACCGCAAAC }\end{array}$ & 118 & Thioredoxin reductase 2 \\
\hline TXNRD3 (NM_001192109) & $\begin{array}{l}\text { F: CAGCACGCGGGTTAAAGAAC } \\
\text { R: CTGGTGATCTCCGACAGAGC }\end{array}$ & 114 & Thioredoxin reductase 3 \\
\hline $\begin{array}{l}\text { SelM } \\
(\text { NM_001163171) }\end{array}$ & $\begin{array}{l}\text { F:ACTGGAACCGTCTACAAGGC } \\
\text { R:GGATGTCCTGGGTGACGAAG }\end{array}$ & 105 & Selenoprotein M \\
\hline SelT (NM_001103103) & $\begin{array}{l}\text { F: TTTTGCAAGAGCAGCGTGAC } \\
\text { R: AAGAGGTACAACGAGCCTGC }\end{array}$ & 102 & Selenoprotein $\mathrm{T}$ \\
\hline SelW (NM_001163225) & $\begin{array}{l}\text { F: CTAGCCGTCTGGACATCTGC } \\
\text { R: TGGAGTGAACCAGCTTTCCC }\end{array}$ & 87 & Selenoprotein W \\
\hline SelH (NM_001164092) & $\begin{array}{l}\text { F: GCTTCGAGGTGACGTTGCTG } \\
\text { R:CTGCCCCACCTCCCTACGA }\end{array}$ & 150 & Selenoprotein $\mathrm{H}$ \\
\hline SelK (NM_001037489) & $\begin{array}{l}\text { F:AGGCTACGGAAGCTCATCTG } \\
\text { R: CGGCCATTGGAGGAGGATTA }\end{array}$ & 122 & Selenoprotein K \\
\hline SelI (NM_001075257) & $\begin{array}{l}\text { F: ACAAGCATGTACCCGACTGG } \\
\text { R: GAATTGGTTCTGCGGGCTTG }\end{array}$ & 103 & Selenoprotein I \\
\hline SelO (NM_001163193) & $\begin{array}{l}\text { F: CCACGTTCCTCAGGTTTGGA } \\
\text { R: ATCTGCAGTCGGATGTCGTC }\end{array}$ & 103 & Selenoprotein $\mathrm{O}$ \\
\hline SelS (NM_001046114) & $\begin{array}{l}\text { F: CCCACCCTCGAGACCGA } \\
\text { R: ATGTACCAGCCGTAAGTGGC }\end{array}$ & 77 & Selenoprotein S \\
\hline SelF (NM_001034759) & $\begin{array}{l}\text { F: TTGGGGAGGTTCCCTCAAGT } \\
\text { R: AGCAATGTTCCCACTGTCGT }\end{array}$ & 132 & Selenoprotein F \\
\hline SelV (NM_001163244) & $\begin{array}{l}\text { F: CCATCCAGGCCATCTTACCG } \\
\text { R: AGGCCACAGTAAACCACTCG }\end{array}$ & 103 & Selenoprotein V \\
\hline
\end{tabular}

of Se/head, respectively. The plasma Se of control and NanoSe groups $(110.13 \mu \mathrm{g} / \mathrm{L}$ vs $137.49 \mu \mathrm{g} / \mathrm{L})$ was within normal limits.

The scientific literature on the effects of Se on lactation performance is inconclusive. Several studies found that dietary Se has no significant effect on milk yields and components $[25,26]$. On the contrary, other studies found that Se may result in lower milk protein [27], decreased milk fat [13] and higher milk yields [28]. These results could be due to differences in Se forms and doses/or the composition of the diet. The present research supports a general view that dietary Se sources are unlikely to significantly affect milk yield or composition [11].

Increased serum GSH-Px activity with Nano-Se supplementation has been reported in laying hens [15]. Similarly, in the current experiment, Nano-Se increased both Se levels
Table 3 Effects of Nano-Se supplementation on lactation performance and milk composition of dairy cows $(n=6)$

\begin{tabular}{|c|c|c|c|c|c|c|}
\hline \multirow[b]{2}{*}{ Item } & \multirow[t]{2}{*}{ Control } & \multirow[t]{2}{*}{ Nano-Se } & \multirow[b]{2}{*}{ SEM } & \multicolumn{3}{|l|}{$P$ value } \\
\hline & & & & Treatment & Time & Treat $\times$ time \\
\hline DMI (kg/day) & 13.45 & 13.28 & 0.35 & 0.74 & 0.17 & 0.79 \\
\hline Milk yield (kg/day) & 26.74 & 27.44 & 0.64 & 0.36 & 0.11 & 0.19 \\
\hline Milk protein (\%) & 3.34 & 3.50 & 0.10 & 0.31 & 0.63 & 0.32 \\
\hline Milk fat (\%) & 3.37 & 3.33 & 0.22 & 0.87 & 0.79 & 0.80 \\
\hline Milk lactose (\%) & 4.87 & 4.86 & 0.05 & 0.94 & 0.66 & 0.67 \\
\hline Milk Se $(\mu \mathrm{g} / \mathrm{L})$ & 23.19 & 30.60 & 1.55 & $<0.01$ & $<0.01$ & $<0.01$ \\
\hline
\end{tabular}




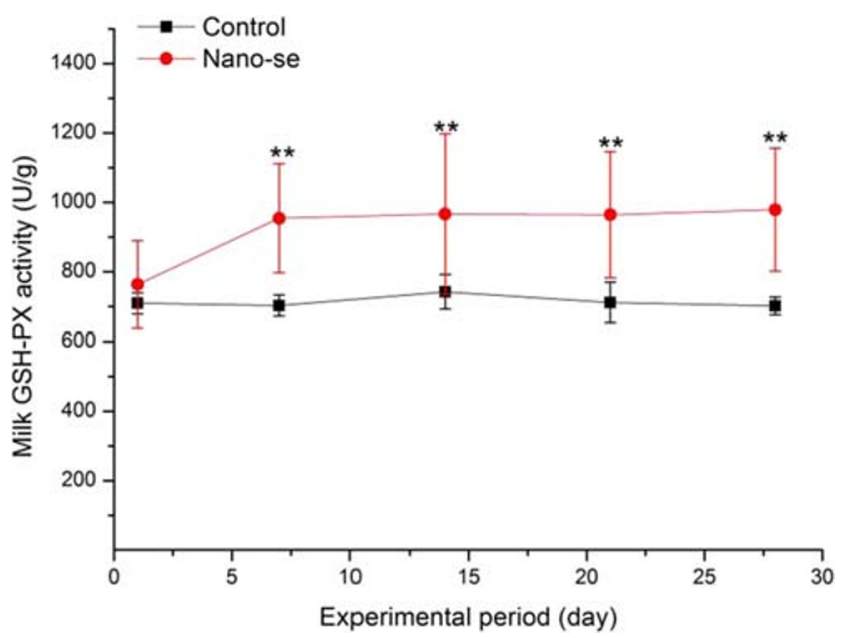

Fig. 1 Effect of Nano-Se supplementation on the milk GSH-Px activity. Data are presented as the mean \pm SEM. The milk samples were collected on day 1, 7, 14, 21 and 28. One unit of GSH-Px is defined as the amount of enzyme depleting $1 \mu \mathrm{mol}$ of GSH per gram of milk protein $/ 5 \mathrm{~min}$ at $37^{\circ} \mathrm{C} . * P<0.05$ or $* * P<0.01$

and GSH-Px activity in blood compared with sodium selenite supplementation. As an essential component of the antioxidant system, it seems likely that plasma Se enhanced the antioxidant capacity of animals. GSH-Px is important for Secontaining enzymes in the blood of animals, which function as an antioxidant by reducing hydrogen peroxide to water and catalysing the reduction of thioredoxin. GSH-Px activity has been widely adopted as an antioxidant biomarker for oxidative stress in dairy cows [11]. It is clear that cows supplemented with Nano-Se had signs of increased antioxidant status of dairy cows.

Our results showed that Nano-Se was more effective than inorganic Se at increasing the milk Se concentration. A research with broiler chickens has also demonstrated that nanoparticles are more effectively absorbed in comparison with the usual dietary additive, sodium selenite [29]. The difference between Nano-Se and sodium selenite was probably related to the different absorption processes. Interestingly, we also observed that Nano-Se supplementation increased the GSHPx activity of milk whey. GSH-Px is the only enzyme containing Se in milk and its activity is mainly dependent upon the concentration of $\mathrm{Se}$ [30]. Therefore, it is not surprising that Nano-Se supplementation increased milk Se, accompanied by

Table 4 Effects of Nano-Se supplementation on the antioxidant activity of plasma $(n=6)$

\begin{tabular}{lcccc}
\hline Item & Control & Nano-Se & SEM & $P$ value \\
\hline Total Se $(\mu \mathrm{g} / \mathrm{L})$ & 110.13 & 137.49 & 5.89 & $<0.01$ \\
GSH-Px activities $(\mathrm{U} / \mathrm{mL})^{1}$ & 131.20 & 161.53 & 6.49 & $<0.01$ \\
\hline
\end{tabular}

\footnotetext{
${ }^{1}$ One unit of GSH-Px is defined as the amount of enzyme depleting

$1 \mu \mathrm{mol}$ of $\mathrm{GSH} / 5 \mathrm{~min}$ at $37^{\circ} \mathrm{C}$ in $0.1 \mathrm{~mL}$ of serum
}

Table 5 Effects of Nano-Se supplementation on the mRNA expression of Sel genes in the mammary gland of dairy cows $(n=5)$

\begin{tabular}{llllr}
\hline Gene & Control & Nano-Se & SEM & $P$ value \\
\hline GPX1 & 0.64 & 1.54 & 0.12 & $<0.01$ \\
GPX2 & 0.82 & 1.58 & 0.07 & $<0.01$ \\
GPX3 & 1.18 & 1.39 & 0.16 & 0.33 \\
GPX4 & 0.49 & 1.52 & 0.08 & $<0.01$ \\
TXNRD1 & 0.91 & 1.32 & 0.25 & 0.21 \\
TXNRD2 & 0.63 & 1.64 & 0.24 & 0.02 \\
TXNRD3 & 0.90 & 1.25 & 0.06 & $<0.01$ \\
SelM & 1.27 & 1.23 & 0.25 & 0.91 \\
SelW & 0.90 & 1.20 & 0.54 & 0.02 \\
SelT & 0.90 & 1.58 & 0.12 & $<0.01$ \\
SelH & 0.88 & 1.29 & 0.09 & 0.19 \\
SelK & 1.01 & 1.52 & 0.12 & 0.01 \\
SelI & 0.97 & 1.11 & 0.05 & 0.06 \\
SelO & 0.84 & 1.00 & 0.08 & 0.16 \\
SelS & 1.05 & 1.32 & 0.11 & 0.06 \\
SelF & 0.84 & 1.31 & 0.18 & 0.04 \\
SelV & 1.01 & 1.05 & 0.04 & 0.51 \\
\hline
\end{tabular}

increased GSH-Px activity in milk. The antioxidant capacity of milk and dairy products is mainly due to Se and Secontaining enzyme [31]. The increase in milk Se content and GSH-PX activity that we detected suggests that antioxidant activity of milk could be enhanced by Nano-Se supplementation.

Se exists in the form of selenoproteins (Sels) that play important biological function in dairy cows [13]. The upregulated GPX mRNA expression and GSH-PX activity that we detected indicated that Sel expression of mammary regulated the activities of milk Se-containing enzyme. It has been reported that the Se levels play a regulatory role for Sels, and Sel expression in animal tissues and cells were induced by Selenium supplement [32-34]. Since in the present study, nano-Se supplement resulted in significantly upregulated Sel mRNA expression (GPX, TXNRD, SelW, T, K and F), it is suggested that Se status is an important regulator of selenoprotein activity and expression in the mammary gland of dairy cows.

\section{Conclusion}

Nano-Se was more effective than sodium selenite at improving antioxidant status and increasing milk Se levels of dairy cows. The Sel expression was increased in the mammary gland tissue of dairy cows with Nano-Se supplement when compared with sodium selenite supplementation. The present 
findings provide initial evidence of benefits of Nano-Se supplementation in dairy cows.

Funding Information This research was jointly supported by the China Agriculture Research System (CARS-36), the National Natural Science Foundation of China (U1904116) and the Foundation of Bosar Biotechnology Research Company.

\section{Compliance with Ethical Standards}

All experimental procedures were approved by the Animal Care and Use Committee of Henan Agricultural University, which was performed according to the Guidelines for Experimental Animal of the Ministry of Science and Technology (2006, Beijing, China).

Conflict of Interest The authors declare that they have no conflict of interest.

Open Access This article is licensed under a Creative Commons Attribution 4.0 International License, which permits use, sharing, adaptation, distribution and reproduction in any medium or format, as long as you give appropriate credit to the original author(s) and the source, provide a link to the Creative Commons licence, and indicate if changes were made. The images or other third party material in this article are included in the article's Creative Commons licence, unless indicated otherwise in a credit line to the material. If material is not included in the article's Creative Commons licence and your intended use is not permitted by statutory regulation or exceeds the permitted use, you will need to obtain permission directly from the copyright holder. To view a copy of this licence, visit http://creativecommons.org/licenses/by/4.0/.

\section{References}

1. Zhang L, Zeng HW, Cheng WH (2018) Beneficial and paradoxical roles of selenium at nutritional levels of intake in healthspan and longevity. Free Radic Biol Med 127:3-13. https://doi.org/10.1016/ j.freeradbiomed.2018.05.067

2. Peng X, Cui Y, Cui W, Deng J, Cui H (2009) The decrease of relative weight, lesions, and apoptosis of bursa of fabricius induced by excess dietary selenium in chickens. Biol Trace Elem Res 131(1):33-42. https://doi.org/10.1007/s12011-009-8345-6

3. Moir DC, Masters HG (1979) Hepatosis dietetica, nutritional myopathy, mulberry heart disease and associated hepatic selenium level in pigs. Aust Vet J 55(8):360-364

4. Gandin V, Khalkar P, Braude J, Fernandes AP (2018) Organic selenium compounds as potential chemotherapeutic agents for improved cancer treatment. Free Radic Biol Med 127:80-97. https:// doi.org/10.1016/j.freeradbiomed.2018.05.001

5. Lubinski J, Marciniak W, Muszynska M, Huzarski T, Gronwald J, Cybulski C, Jakubowska A, Debniak T, Falco M, Kladny J, Kotsopoulos J, Sun P, Narod SA (2018) Serum selenium levels predict survival after breast cancer. Breast Cancer Res Treat 167(2):591-598. https://doi.org/10.1007/s10549-017-4525-9

6. Kuria A, Fang X, Li M, Han H, He J, Aaseth JO, Cao Y (2018) Does dietary intake of selenium protect against cancer? A systematic review and meta-analysis of population-based prospective studies. Crit Rev Food Sci Nutr:1-11. https://doi.org/10.1080/ 10408398.2018.1548427

7. Knowles SO, Grace ND, Knight TW, McNabb WC, Lee J (2004) Adding nutritional value to meat and milk from pasture-fed livestock. N Z Vet J 52(6):342-351. https://doi.org/10.1080/ 00480169.2004 .36450

8. Juniper DT, Phipps RH, Givens DI, Jones AK, Green C, Bertin G (2008) Tolerance of ruminant animals to high dose in-feed administration of a selenium-enriched yeast. J Anim Sci 86(1):197-204. https://doi.org/10.2527/jas.2006-773

9. Ceballos A, Sanchez J, Stryhn H, Montgomery JB, Barkema HW, Wichtel JJ (2009) Meta-analysis of the effect of oral selenium supplementation on milk selenium concentration in cattle. J Dairy Sci 92(1):324-342. https://doi.org/10.3168/jds.2008-1545

10. Sun P, Wang J, Liu W, Bu DP, Liu SJ, Zhang KZ (2017) Hydroxyselenomethionine: a novel organic selenium source that improves antioxidant status and selenium concentrations in milk and plasma of mid-lactation dairy cows. J Dairy Sci 100(12):9602-9610. https://doi.org/10.3168/jds.2017-12610

11. Gong J, Ni LL, Wang DF, Shi BL, Yan SM (2014) Effect of dietary organic selenium on milk selenium concentration and antioxidant and immune status in midlactation dairy cows. Livest Sci 170:84 90. https://doi.org/10.1016/j.livsci.2014.10.003

12. Seboussi R, Tremblay GF, Ouellet V, Chouinard PY, Chorfi Y, Belanger G, Charbonneau E (2016) Selenium-fertilized forage as a way to supplement lactating dairy cows. J Dairy Sci 99(7):5358 5369. https://doi.org/10.3168/jds.2015-10758

13. Sun LL, Gao ST, Wang K, Xu JC, Sanz-Fernandez MV, Baumgard LH, Bu DP (2019) Effects of source on bioavailability of selenium, antioxidant status, and performance in lactating dairy cows during oxidative stress-inducing conditions. J Dairy Sci 102(1):311-319. https://doi.org/10.3168/jds.2018-14974

14. Zhang JS, Gao XY, Zhang LD, Bao YP (2001) Biological effects of a nano red elemental selenium. BioFactors 15(1):27-38

15. Meng TT, Liu YL, Xie CY, Zhang B, Huang YQ, Zhang YW, Yao YJ, Huang RL, Wu X (2019) Effects of different selenium sources on laying performance, egg selenium concentration, and antioxidant capacity in laying hens. Biol Trace Elem Res 189(2):548 555. https://doi.org/10.1007/s12011-018-1490-z

16. Zhang JS, Wang XF, Xu TW (2008) Elemental selenium at nano size (Nano-se) as a potential chemopreventive agent with reduced risk of selenium toxicity: comparison with se-methylselenocysteine in mice. Toxicol Sci 101(1):22-31. https://doi.org/10.1093/toxsci/ $\mathrm{kfm} 221$

17. Han L, Batistel F, Ma Y, Alharthi ASM, Parys C, Loor JJ (2018) Methionine supply alters mammary gland antioxidant gene networks via phosphorylation of nuclear factor erythroid 2-like 2 (NFE2L2) protein in dairy cows during the periparturient period. J Dairy Sci 101(9):8505-8512. https://doi.org/10.3168/jds.201714206

18. Fradejas-Villar N (2018) Consequences of mutations and inborn errors of selenoprotein biosynthesis and functions. Free Radic Biol Med 127:206-214. https://doi.org/10.1016/j.freeradbiomed. 2018.04.572

19. Liu HM, Jin JB, Zhou J, Huang KX, Xu HB (2018) The structure and function of Selenoprotein $\mathrm{S}$ and its relationship with diseases. Prog Chem 30(10):1487-1495. https://doi.org/10.7536/PC180613

20. Short SP, Williams CS (2017) Selenoproteins in tumorigenesis and Cancer progression. Adv Cancer Res 136:49-83. https://doi.org/10. 1016/bs.acr.2017.08.002

21. Short SP, Pilat JM, Williams CS (2018) Roles for selenium and selenoprotein $\mathrm{P}$ in the development, progression, and prevention of intestinal disease. Free Radic Biol Med 127:26-35. https://doi. org/10.1016/j.freeradbiomed.2018.05.066

22. Liang Y, Lin SL, Wang CW, Yao HD, Zhang ZW, Xu SW (2014) Effect of selenium on selenoprotein expression in the adipose tissue of chickens. Biol Trace Elem Res 160(1):41-48. https://doi.org/10. 1007/s12011-014-0024-6

23. Bionaz M, Loor JJ (2007) Identification of reference genes for quantitative real-time PCR in the bovine mammary gland during 
the lactation cycle. Physiol Genomics 29(3):312-319. https://doi. org/10.1152/physiolgenomics.00223.2006

24. Dargatz DA, Ross PF (1996) Blood selenium concentrations in cows and heifers on 253 cow-calf operations in 18 states. J Anim Sci 74(12):2891-2895. https://doi.org/10.2527/1996.74122891x

25. Juniper DT, Phipps RH, Jones AK, Bertin G (2006) Selenium supplementation of lactating dairy cows: effect on selenium concentration in blood, milk, urine, and feces. J Dairy Sci 89(9):3544-3551. https://doi.org/10.3168/jds.S0022-0302(06)72394-3

26. Givens DI, Allison R, Cottrill B, Blake JS (2004) Enhancing the selenium content of bovine milk through alteration of the form and concentration of selenium in the diet of the dairy cow. J Sci Food Agric 84(8):811-817. https://doi.org/10.1002/Jsfa.1737

27. Calamari L, Petrera F, Bertin G (2010) Effects of either sodium selenite or se yeast (Sc CNCM I-3060) supplementation on selenium status and milk characteristics in dairy cows. Livest Sci 128(13):154-165. https://doi.org/10.1016/j.livsci.2009.12.005

28. Wang C, Liu Q, Yang WZ, Dong Q, Yang XM, He DC, Zhang P, Dong KH, Huang YX (2009) Effects of selenium yeast on rumen fermentation, lactation performance and feed digestibilities in lactating dairy cows. Livest Sci 126(1-3):239-244. https://doi.org/10. 1016/j.livsci.2009.07.005

29. Hu CH, Li YL, Xiong L, Zhang HM, Song J, Xia MS (2012) Comparative effects of nano elemental selenium and sodium selenite on selenium retention in broiler chickens. Anim Feed Sci Technol 177(3-4):204-210. https://doi.org/10.1016/j.anifeedsci. 2012.08.010
30. Khan IT, Nadeem M, Imran M, Ullah R, Ajmal M, Jaspal MH (2019) Antioxidant properties of Milk and dairy products: a comprehensive review of the current knowledge. Lipids Health Dis 18: ARTN 41. https://doi.org/10.1186/s12944-019-0969-8

31. Wang YC, Yu RC, Chou CC (2006) Antioxidative activities of soymilk fermented with lactic acid bacteria and bifidobacteria. Food Microbiol 23(2):128-135. https://doi.org/10.1016/j.fm.2005. 01.020

32. Wang FH, Peng X, Chen Y, Wang Y, Yang M, Guo MY (2019) Se regulates the contractile ability of uterine smooth Musclevia Selenoprotein N, Selenoprotein T, and Selenoprotein win mice. Biol Trace Elem Res 192:196-205. https://doi.org/10.1007/ s12011-019-1647-4

33. Ren B, Huang Y, Zou C, Wu Y, Huang Y, Ni J, Tian J (2019) Transcriptional regulation of Selenoprotein $\mathrm{F}$ by heat shock factor 1 during selenium supplementation and stress response. Cells 8(5). https://doi.org/10.3390/cells8050479

34. Gao YH, Zhang JL, Huang XD, Zhang GX (2017) Glutathione peroxidase 1, Selenoprotein K, and Selenoprotein $\mathrm{H}$ may play important roles in chicken testes in response to selenium deficiency. Biol Trace Elem Res 179(2):271-276. https://doi.org/10.1007/ s12011-017-0953-y

Publisher's Note Springer Nature remains neutral with regard to jurisdictional claims in published maps and institutional affiliations. 